\title{
Roderick Anthony Cawson
}

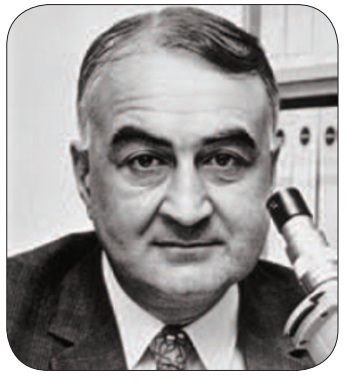

Roderick Cawson died on 25 April, just two days after his eighty-sixth birthday, in King's College Hospital where he had qualified 60 years earlier, first in dentistry and subsequently in medicine.

After serving in the RAF from 1944-8, Rod was appointed to a Senior Lectureship in the Department of Oral Pathology at King's College London. He obtained his MD degree from London University and later the FRCPath.

In 1962, he became Senior Lecturer in the Department of Dental Medicine at Guy's Hospital Dental School. In 1966, he was appointed Head of the new Department of Oral Medicine and Pathology and not long afterwards to the established University of London Chair of Oral Medicine and Pathology that he held until his retirement in 1986.

On retirement, Rod's work accelerated as he achieved Emeritus status. He continued to contribute to the UK Salivary Gland Tumour Panel, and write his texts from the Guy's Department of Surgery and the Eastman Dental Hospital.

Rod received many awards and appointments for his academic achievements. He was the first to carry out a statistical survey of

\section{Gwilym Ieuan (GI) Davies}

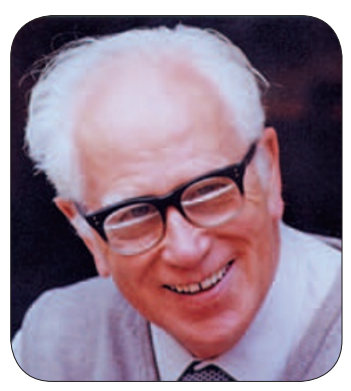

Gwilym Ieuan (GI) Davies died on 23 February 2007, ten days after his eighty-fourth birthday. A very bright, intelligent young man, he commenced university aged 16 and remains the youngest dental graduate from Manchester. He joined the RAF on graduation in 1945 and this is where he met his wife Jeanne who sadly died last year. GI set up practice at 3 High Street Bethesda in December 1948. He worked full time until he was 72, single handed for many years until he was joined by his daughter Judi in 1973. GI has four children and all three of his daughters followed him into dentistry. He would have carried on working longer but was afflicted by Parkinson's disease which gradually stilled his cheerful voice and rendered his expressive face immobile.

Quality was his trademark and people beat a path to his door. He was a member of many committees, a past president of his branch of the BDA and a life member of the Association. In 1979 he became one of the first cohort to achieve the MGDS. He was also a life member of this Association. He was awarded an FFGDP (UK) in March 2001 in recognition of his service to dentistry.

\section{Rod was revered by all and sought out for his encyclopaedic knowledge.}

oral cancer in England and Wales, the first to describe the features of oral tuberculosis following the introduction of chemotherapy and to recognise the malignant potential of chronic candidiasis. He made a significant contribution to our understanding of candidiasis. But, above all, Rod was an outstandingly gifted author, producing a litany of extremely readable textbooks which became standard undergraduate and postgraduate reading.

Rod was revered by all and sought out for his many talents and encyclopaedic knowledge. He was engaging with an infectious sense of humour that was always in good taste. He had a love for Suffolk and its countryside in which Rod and his wife Diana had an Elizabethan cottage. Dentistry owes a lot to Diana, who supported him for all those years as he churned out text after text. The night that he died, Rod said goodbye to Diana, his lifelong love and companion. With a smile on his face, he said 'now, don't burn my books and papers.' No Rod, we can't do that. You will live on in these for many decades to come.

M. Gleeson, M. N. Naylor

\section{Quality was his trademark and people beat a path to his door.}

With a camera in his hand he had the uncanny knack of producing a smile from his subject and he developed and printed his own work late in the evenings after closing the surgery and at weekends when he was not on the golf course. He gained many qualifications from the Royal Photographic Society for portraits, aerial photography and medical work. His slides and films of maxillofacial surgery were used around the world by Gordon Hardman for whom he was an associate specialist at the old CCtA hospital in Bangor. When Dame Margaret Seward was the editor of the $B D J$ he photographed many of the BDA conferences for her. Photographic contributions to BSGDS functions have been used in many of their publications over the years. Two books have been published of his aerial photography of North Wales. His aerial photographs have also been used in historical videos of the area and have been archived.

The world is a poorer place with the loss of 'The Boss', 'Davies Dentist', who is sadly missed by his extensive family and many friends.

Jane Moore, Judi Lentelink, Robert Davies \&t Jenny Herold 